\title{
A multiplicidade de temas e abordagens na área da Geriatria e Gerontologia
}

Multiple themes and approaches in the field of Geriatrics and Gerontology

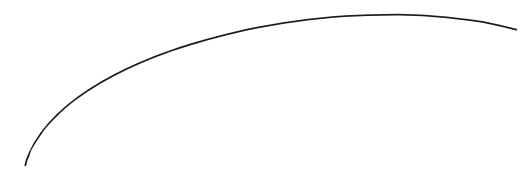

Chegamos ao último número do ano de 2010 da Revista Brasileira de Geriatria e Gerontologia RBGG. Podemos observar a consolidação não só da área do envelhecimento humano, mas também da Revista.

O número de artigos recebidos e, principalmente, a qualificação dos autores e as temáticas variadas dos artigos confirmam esta minha afirmação. Hoje a RBGG está presente em todos os congressos, encontros, jornadas e seminários da área, e os autores são de vários estados brasileiros, o que vem a confirmar que ela é um instrumento científico difundido em todo o país.

Neste número, algumas das principais conferências da VIII Jornada Brasileira de Enfermagem Geriátrica e Gerontológica estão entre os artigos apresentados. Neles são discutidos temas de importância para a constituição das políticas públicas de saúde que vêm sendo implantadas pelo Ministério da Saúde. A importância da equipe de saúde no contexto do idoso é algo que não pode faltar ao debate contemporâneo no Brasil. Do mesmo modo, pois achamos que o campo do envelhecimento é muito amplo e que nenhum tema deve ser descartado, discute-se também em mais de um artigo o papel das instituições de longa permanência. O asilamento é tema extremamente controverso, mas que não pode deixar de ser enfrentado por aqueles que trabalham na área.

E em outra perspectiva, de política macro e integrativa, uma das propostas mais exitosas da Organização Mundial de Saúde quando da gestão do brasileiro Dr. Alexandre Kalache - que é a criação de espaços mais adequados para a inclusão dos idosos na cidade, sob todos os aspectos, consubstanciada na bandeira Cidade Amiga dos Idosos -, também está presente neste número da RBGG. O artigo que apresenta este tema vem de Portugal, o que vem reforçar a importância desta discussão, pois temas relevantes são universais e todos os países têm a aprender com as experiências bem-sucedidas.

A contribuição da epidemiologia na determinação dos fatores de risco também faz parte da preocupação dos pesquisadores da área, e é aqui apresentada em um artigo que traz dados do risco da mortalidade em idosos submetidos a cirurgias abdominais.

A variedade de tópicos é enorme; este número cobre questões sobre nutrição, atividade física, centro de convivência, a fala e as dificuldades de alguns vocábulos, farmacoterapia, entre outros assuntos abordados. Mas como estamos tratando de uma área em que a multiplicidade de saberes se faz necessariamente presente, em uma revista que tem esta visão do todo, sempre se encontram outros temas, como, por exemplo, a visão dos avós e de seus netos. Este é um assunto novo, pois com a ampliação do tempo de vida, cada vez mais se 
observa o aumento do número de anos que as pessoas vivem com seus avós. Neste sentido, os programas intergeracionais se ampliam e contribuições qualificadas são também discutidas neste número da Revista.

Procurei apresentar, aqui, um panorama dos manuscritos e apresentar ao o leitor da RBGG a imensidade de assuntos estimulantes que compõem o presente número da Revista. $O$ compromisso da UnATI é uma formação integral e a qualificação dos profissionais da área, e este número da RBGG reflete nossa preocupação em trazer para todos que militam na área do envelhecimento humano muitas informações de campos e perspectivas diversas, pois compreendemos que o geriatra e o gerontólogo devem ter uma preocupação bastante ampla.

A UnATI e a RBGG esperam que este número da Revista Brasileira de Geriatria e Gerontologia reafirme o nosso compromisso pedagógico de uma formação ampla e qualificada. E aproveito que estamos na reta final do ano para desejar a todos um feliz 2011. 